universities].Khortyng theory and methods, 2, pp. 55-62. [in Ukrainian].

5. Melnikova, O. V. (2012). Problemy patriotychnoho vykhovannia suchasnoi molodi [Issues of patriotic education of modern youth]. Spirituality of the person: methods, theory and practice, 2, pp. 83-89. [in Ukrainian.

6. Voytko, V. I. (Ed.) (1982). Psikhologicheskiy slovar [Psychological glossary]. Kyiv:Main publishing house of publishing unity "Vyshcha shkola", 218 p. [in Ukrainian.

7. Semchenko, N. O. (2004). Pedahohichni umovy formuvannia liderskykhy akostei maibutnikh uchyteliv u pozaaudytornii diialnosti [Pedagogical conditions of formation of leadership attributes of future teachers during extracurricular activities]. Candidate's thesis. Kharkiv, 215 p. [in Ukrainian].

8. Sopivnyk, R. V. (2015). Formuvannia liderskykhy akostei maibutnikh fakhivtsiv ahropromyslovoi haluzi [Formation of leadership attributes of future specialist in agriculture]. Spirituality of the person: methods, theory and practice, 4, pp. 149-160. [in Ukrainian].

9. Sushyk, N. (2013). Teoretychni osnovy formuvannia liderskykhy akostei uchnivskoi molodi [Theoretical basis of formation of pupils' leadership attributes]. Bulletin of Lesya Ukrainka Eastern European National University. Lutsk, pp. 110-115. [in Ukrainian].

Стаття надійшла до редакції 30.07.2018

УДК 793.31

DOI:

Петро Фриз, кандидат мистеитвознавства, доиент кафедри культурології та мистеиьккої освіти Дрогобицького державного педагогічного університету імені Івана Франка

\title{
УКРАЇНСЬКІ ХОРЕОГРАФІЧНІ ТРАДИЦІЇ ЯК ВІДОБРАЖЕННЯ СОЩІОКУЛТУРНОГО ДОСВІДУ
}

У статті розвинуто концептуальний підхід до аналізу украйнських хореографічних традицій, в основу якого покладено розуміння хореографічної творчості як осмислення буття через картину внутрішнього світу людини. Проаналізовано культуротворчу функиію українського таниювального мистецтва, актуалізацію фольклорних канонів, оновлення народних традицій та їх включення у сучасну хореографічну культуру.

Така феноменологічна спеиифікаиія хореографічного мистеитва як мистеитва наскрізь умовного $i$ опосередкованого виявляється у принщипі єдності виконання і виховання, визначаючи значення танцю як вихідної умови існування.

Ключові слова: танець; хореографічне мистеитво; хореографічна традиція; українська народносиенічна хореографія; народна танцювальна творчість; соиіокультурний досвід.

Jim. 6.

Petro Fryz, Ph.D.(Study of Art), Associate Professor of the Cultural Studies and Artistic Education Department Drohobych Ivan Franko State Pedagogical University

\section{UKRAINIAN CHOREOGRAPHIC TRADITIONS AS REFLECTION OF THE CULTURAL AND SOCIAL EXPERIENCE}

The new conceptual approach to the researches of the Ukrainian choreographic traditions has been developed in the article. This approach is based upon the phenomenological comprehension as the particular contemplation of the existence within one's personal inner world. The ? ultural function of Ukrainian dancing art, actualization of folk canons, updating of folk traditions in a modern choreographic culture are analysed. Folk dance is the transmitter of cultural code of people, incarnates the important lines of national culture, is the repeater of the system of values (public traditions, norms, standards, ideals and others). With the aid of the mediation of the means of this inner world's revelation choreographic traditions comes to existence as a specific system of choreographic conventions where the general paradox of performance is displayed, namely that of the productivity of reproduction and retrospection. Reflection and mediation explain the paradoxical stability and productivity of this canon as well as that of the minimalistic selfrestriction coming to the extreme conditions of an artistic experiment. A particular actuality of the choreographic space and time has been stressed. Such phenomenological specification of choreographic art as the conventional and mediated art mainly finds its revelation in the principle of the unity of performance and instruction. The traditions, tendency and law of figurative-semantic transformation of the traditional 
forms of both lexicon of folk dance during synthesis with the professional choreographic art are considered in close of connection.

Keywords: dance; choreographic art; choreographic tradition; staged folk Ukrainian choreography; folk dance culture; cultural and social experience.

П остановка проблеми. Українська хореографічна культура як цілісна система художніх смислів з відповідною логікою культурно-історичного процесу, що звернена до людської суб'єктивності, є предметом сучасних досліджень. Народний танець $є$ носієм культурного коду народу, втілює важливі риси національної культури, $є$ ретранслятором системи цінностей (суспільні традиції, норми, зразки, ідеали тощо). Хореографічні традиції дають найбільш точне уявлення про пластичну лексику. В жодному з мистецтв вона не відіграє такої ролі, як у хореографії. Використовуючи танцювальну лексику, сучасні хореографи у кожному оригінальному творі використовують традиційні рухи, відображаючи таким чином соціокультурний досвід народу.

Аналіз останніх досліджень і публікацій. Вагомий внесок у дослідження хореографічної культури зробили відомі дослідники: В. Авраменко [1], К. Василенко [2], В. Верховинець [3], В. Шкоріненко [5]. Предметом їх грунтовного аналізу є становлення і розвиток сценічної хореографічної культури України, зокрема проблема синтезу класичного та народного танцю, що важливо в контексті нашого дослідження. Як відзначає А.Гоцалюк, наукові розробки К. Василенка, І. Книша, С. Легкої, I. Пігуляка дають можливість осмислити танець (зокрема, український народний танець) як соціально-культурний та мистецький феномен [4] Досліджуючи лексичні новотворення, ці дослідники акцентували свою увагу перш за все на рухах традиційної хореографії, не оминаючи увагою тих трансформацій народного танцю, що виникли внаслідок поєднання, ускладнення існуючих форм руху або окремих його елементів, а також па, створених балетмейстерами заново 3 ресурсів народно-сценічного танцю.

Мета статті - дослідити хореографічні традиції в контексті формування соціокультурного досвіду українців.

Виклад основного матеріалу. Важливим елементом внутрішньої структури духовності особистості $\epsilon$ мотиви, які формують ставлення особистості до інтересів, потреб, цінностей, орієнтацій. Практичне ставлення людини до тих чи інших явищ діяльності внутрішньо детерміноване не лише уявленнями, думками про цінності, але й відповідним емоціями. Соціальна поведінка особистості складає внутрішньо суперечливу єдність раціонального й емоційного. Мотив - це те, що спонукає діяльність людини. У нашому випадку - це створення таких зразків хореографічної культури, що будуються в ході осмислення митцем соціокультурного досвіду, художньо-естетичних ідеалів. Мистецтво змушує глядача сформувати естетичну оцінку, зробити їі власним відношенням до світу і до самої себе. Таке органічне засвоєння $є$ наслідком естетичного переживання. Хореографічна культура, як і інші сфери художньої культури, пропускає через естетичний фільтр відношення не тільки усталені суспільством, але й сформовані індивідом. Саме це забезпечує творчість митця, нові проекти, їх впровадження в структуру духовності особистості з мотивацією нових потреб.

Цілісним суб' єктом суспільства індивід стає в міру засвоєння і прийняття відповідних соціальних норм, що регулюють життєдіяльність людини і суспільства. Завдяки соціальним нормам розрізнені індивідуальні дії та вчинки інтегруються у систему суспільних відносин, формуючи певний соціальний порядок. Осягнути винятковість особистості, іiі тип можна дослідивши соціальні норми, яких вона дотримується не з примусу, а з переконань їх необхідності, правомірності, справедливості, їх збігові з ціннісними орієнтаціями індивіда.

Важливою характеристикою соціальної спрямованості особи є іiї соціальний потенціал нахили, здібності, знання, вміння, навички, що визначають спосіб, технологію, майстерність людської діяльності, її ефективність. Особливо яскравим є соціальний потенціал художньої культури. Соціальний потенціал хореографічної культури практично не вивчений. Втім можна впевнено стверджувати, що вона $є$ могутнім чинником формування соціальної поведінки і впливу на суспільні відносини в цілому.

Хореографічне мистецтво видовищне, виконавське i грунтується на музичному сприйнятті. Головним його твором є танець, вистава. Умовно хореографічну культуру можна поділити на класичну, народну, модерну. В сучасній культурі успішно функціонує класичний балет. Завдяки творчим пошукам балетмейстерів мистецтво народного танцю стало професійним. Упродовж останніх десятиліть поширення набув модерн, який характеризується не тільки елементами класики, народного, спортивного танцю, але й елементами імпровізації, джазу, 
вуличних танців, степу та інші. Модерн - типовий продукт масової культури ХХ ст. На жаль, національна хореографічна культура, сприймаючи як належне існування західних танцювальних течій і взірців, механічно, не критично переносить їх, не адаптуючи до власних умов, ментальності.

Сучасна хореографічна культура виявляє властиву їй особливість: у художньому творі вирізняються дві сторони - наявна, актуалізована у відтворенні, і потенційна, що розкривається в ході сприймання глядачем. Їх єдність дозволяє судити про художньо-естетичний зміст твору. Отже, художня модель дійсності (спосіб формування художнього образу) вимагає об'єднавчих творчих зусиль автора, виконавця, глядача. Звичайно, художня модель містять не тільки результати, але осмислений досвід, пізнання відношень, усталені стереотипи, оцінки. Мистецтво моделює процес накопичення досвіду, шлях пошуків і сумнівів, рух через втрати до знахідок і втягує читача, глядача, слухача до цього процесу. Художня модель отримує завершеність тоді, коли особистість докладає у створений автором образ свій власний пошук. Особистість проектує хід мислення художника на себе і на своє життєве оточення. Лише такий сплав є завершеною художньою моделлю, що відповідає практичному призначенню мистецтва [6].

Проте процес такого відтворення (проектування) не $\epsilon$ абсолютно вільним. Він суворо заданий твором, ним організується, спрямовується і навіть своєрідно контролюється. Тому в тих ідеальних моделях, які формує свідомість митця, яскраво виявляються дві взаємопов'язані частини: відображувана - до неї входять результати пізнання і оцінки дійсності, і проектувальна - до неї входить програма впливу на майбутнього глядача. Саме в ній доцільно розрізнити сугестивний аспект (функцію), тобто вплив шляхом своєрідного художнього навіювання способу мислення, почуттів, вражень глядача певним ставленням до відображеного художником предметного матеріалу, та інтелектуальний аспект, тобто вплив шляхом збудження певного потоку спостережень, переживань, роздумів, що приводить глядача до певних ідей, оцінок, установок, які мають відношення до тих явищ життя, що відображені у творі, і до тих, що поза межами твору. Проектувальна частина моделі проникає у відображувану. Вона диктує вибір життєвого матеріалу, спрямовую його естетичну оцінку, організацію у художню модель. Відображувана частина моделі $є$ основою проектувальної. Не залучивши глядача до певного потоку життєвих вражень, неможливо ні вразити його задуманим ставленням до них, ні привести до запрограмованих висновків. У такий спосіб виявляється роль втілення ідеальної художньої моделі, що досягається дієвими комунікативними засобами. У хореографічній культурі це пластичне і музичне рішення. До прикладу, хрестоматійні постановки П. Вірського “Запорожці”, “Ой, під вишнею” чи “Повзунець”. Кожна з них має абсолютно різне рішення. Перша композиція присвячена історико-героїчній тематиці, дві інші, на перший погляд, суто побутові. Якщо танець “Ой, під вишнею” $є$ своєрідною ілюстрацією народної пісні, то “Повзунець” ужартівливій формі передає високий мистецький рівень виконання. Але в кожному 3 них митець у найбільш загальному первинному задумі схоплює життя і відношення до нього свого майбутнього глядача, об'єднуючи розрізнені фрагменти в єдиний сюжет. Разом з цим, митець повинен тимчасово відволіктися від матеріалу, щоб конкретизувати ідею твору, і тимчасово відволіктися від ідеї, щоб конкретизувати форму. Лише в їх взаємопроникненні і взаємоперетворенні виникає задум твору, де вони будуть жити як єдине ціле, не знищуючи одне одного. Образ хореографічної форми так глибоко входить в художнє бачення світу, що митець ледь не кожне явище розглядає крізь призму його фізичного (пластичного) втілення. Отже, можна стверджувати, що ідеальна модель у свідомості автора твору відтворює в тих чи інших психофізичних формах результати пізнавальної, оцінної, проектувальної і комунікативної діяльності митця.

Давні слов'яни, як і все людство, витворили такий культурний пласт розвитку, як міфологія, котра як явище історії культури панувала у духовному житті людей протягом десятків тисяч років. У міфологічну епоху образ світобудови відтворювався і закріплювався у системі обрядів, священнодійств, ритуалів, що пронизували всі сторони життя і свідомості архаїчного суспільства. Уявлення про світотворення функціонували за допомогою предметів та зображень, посередництвом особливої організації простору. Уявлення про світопорядок виявлялися в танці, який був центральним елементом усіх традиційних дійств і ритуалів.

Танець $є$ найдавнішою формою художнього самовираження людства. Йому властива здатність людини через рухи висловлювати свої почуття, і водночас танець - це засіб спілкування людини $з$ оточуючим світом, де панує ритм як 
символ Вічності. У сакральних ритуальних дійствах, підставу яких складали сюжети міфів, чільним у структурі був ритм. Він сприймався як організуючий початок світу, якому підпорядковані народження і смерть, природа і людина, найпростіший крок і віртуозні танцювальні па. Ритм і пластичні засоби танцю відкривали шлях до досягнення вищого рівня свідомості, до прориву сили духовної у світ земний. У хореографічній творчості давніх слов'ян знайшли втілення поклоніння небесним світилам тотемічного, зооморфного характеру, вшанування ієрархії антропоморфних богів. Тотемізм як одна 3 форм релігії архаїчного суспільства ототожнював людей і тварин. Саме в цих давніх міфологічних образах викристалізувалась символіка центру, що єднає людину з природою, земним і небесним світом.

В обрядових іграх, хороводах, веснянках знаходили своє відбиття господарські роботи у вигляді поетичного ставлення людини до природи. Відповідні рухи, жести ілюстрували або імітували трудові процеси - сіяння проса, льону, маку тощо. Отже, джерела хореографії криються в праці і побуті, у переодяганнях і вбираннях, якими первісна людина супроводжувала воєнні походи та полювання.

Елементами хореографії були позначені давні звичаї слов' янських народів, пов'язані із зустріччю весни та вигнанням зими. Веснянки на Україні поєднувалися 3 хороводним танцем. Поетичне слово, речитативна мелодія, ритмічний рух - це складові частини хороводу. Перші записи народних хороводів припадають на кінець XVIII - початок XIX ст. В них спостерігаються елементи театралізації - своєрідне змагання, суперечка двох хорів, що по черзі наступають один на одного, і умовна імітація трудових процесів, імпровізаційність, мімічні і пантомімічні деталі, які підкреслюють настрій учасників.

Значення скоморохів урозвитку хореографічної національної культури неможливо переоцінити. Адже до них існувала лише хороводна форма танцю, а з часів скоморохів танці виділилися як окремий жанр мистецтва. Виникли побугові танці. 3 часом більш пізні танці об'єднували ці рухи у складні комбінації - “фігури”. Одним із таких був танець “Козак”, який створили запорозькі козаки. Цей танець став виявом боротьби характерів, відкритим виявом емоцій, змаганням у силі, вправності й творчій фантазії. Козаки прибували на Січ 3 різних регіонів України й зарубіжжя (волохи, молдавани, серби, росіяни, білоруси). Кожен привносив частку своєї хореографічної культури - свої танці. Так поступово створювався новий, багатий на рухи і жести танець - козак.
Упродовж чотирьох століть козаччини українська хореографічна культура збагатилася творчістю запорізьких козаків, які зуміли передати в танцях своє вільне, але суворе ратне життя, і назавжди вписали в історію національного і світового мистецтва образ козака-героя, захисника народу $[6,47]$

У XX ст. Х. Ніжинський, а згодом М. Соболь ускладнюють лексику, збільшуючи амплітуду дії 3 метою здійснення емоційності сприйняття руху. Таким чином, з'явилися різновиди повзунця, присядок, а знання класичного танцю дозволило застосовувати уновій формі композиційні прийоми, що свого часу увійшли до арсеналу класичного балету. Розширюючи значення руху, М. Соболь не перетворив його на самоціль, а вбачав тут образно-дієвий чинник, який у комбінації з іншими допомагав розкрити тему та сюжет твору. Запозичуючи основну структуру руху та забарвлюючи його відповідно до художнього завдання, балетмейстер використовував ряд повітряних рухів, притаманних українському чоловічому танцю.

Реформатором українського хореографічного мистецтва можна вважати П. Вірського. Новаторські пошуки й відкриття цього балетмейстера спираються на традиції української хореографічної й музично-театральної культури, які водночас спираються на глибоке знання законів і лексики класичного балету [3]. Для своїх танцювальних полотен народного танцю, пантоміми, ритмопластики, балетмейстер майстерно об'єднує, “змішує” хореографічні барви, але ніде й ніколи не порушує стилістичної та образної природи національного танцювального мистецтва. Прагнення до різноманітності й виразності танцювальної мови, до її постійного збагачення, до більш точного вибору зображальних засобів виникло у творчості балетмейстера як закономірний результат невтомних шукань, філософського осмислення актуальних проблем нашого життя. Таким чином, джерелами сучасної хореографічної лексики слід вважати виражальні рухи людини, своєрідні мімічно-пантомімічні рухи виявлення емоційних переживань, які $\epsilon$ носіями певного соцокультурного досвіду, виразниками його змісту, а кожне мистецьке явище розглядається в якості носія особливого смислу, зв'язку культурної інформації та коду, розуміння яких є необхідним для всіх видів людської діяльності.

Висновки і перспективи подальших розвідок. Хореографічна культура в єдності змісту і форми здійснює різні функції-соціалізації, інформативно-пізнавальну, естетичну, комунікативну 
та культурно-творчу. Оскільки у статті наукового ступеня кандидата мистецтвознавства. розглядається проблема взаємозв'язку хореографічних традицій і соціокультурного досвіду народу, ми вважаємо за необхідне відзначити культуротворчі можливості танцю. Їх розгляд вимагає системного підходу, бо вони починаються 3 найпростішого засвоєння азів танцювальної культури і завершуються створенням нового мистецького твору, в якому існує єдність життєвого змісту і сюжету, почуття, ставлення один до одного, що виникають у процесі виконавства. Здійснювати культуротворчу функцію, передусім, означає актуалізувати фольклорні канони, народні зразки, а потім створити на їхній основі варіанти, що зберігають для сьогодення значення мистецького взірця й, водночас, забезпечують оновлення традицій та їх включення у сучасну хореографічну культуру.

\section{ЛІТЕРАТУРА}

1. Авраменко В.К. Українські національні танці, музика і стрій / В.Авраменко. - Канада, Вінніпег, 1947. - 80 c.

2. Василенко К.Ю. Лексика українського народно-сценічного танцю / К.Василенко. - 3-те вид. - К.: Мистецтво, 1996. - 493 с.

3. Верховинець В.М. Теорія українського народного танцю / В.Верховинець. - 5-е видання. - К.: Музична Україна, 1990. - 151 с.

4. Гоцалюк А.А. Традиції в розвитку хореографічного мистецтва як віддзеркалення соціокультурної ідентичності / А. А. Гоцалюк // Вісник Харківського національного педагогічного університету імені Г. С. Сковороди. Філософія. 2015. - Вип. 45(1). - С. 16-27.

5. Шкоріненко В.О. Народний танець у традиційній і сучасній культурі України / В.Шкоріненко. Автореферат на здобуття

- K., 2003. - 12 c.

6. Фриз П.І. Хореографічна культура як чинник творчого розвитку особистості дитини: дис... канд. мистецтвознавства: 17.00.01 / Київська держ. академія керівних кадрів культури і мистецтв. - К., 2007. - 181с.

\section{REFERENCES}

1. Avramenko, V. (1947). Ukrainski natsionalni tantsi, muzyka i strii [Ukrainian national dances, music and clothing]. Kanada, Vinnipeh, 80 p. [in Ukrainian].

2. Vasylenko, K. (1996). Leksyka ukrainskoho narodno-stsenichnoho tantsiu [Vocabulary of staged folk Ukrainian dance]. Kyiv: Art, 493 p. [in Ukrainian].

3. Verkhovynets, V. (1990). Teoriia ukrainskoho narodnoho tantsiu [Theory of Ukrainian folk dance]. Kyiv: Musical Ukraine, 151 p. [in Ukrainian].

4. Hotsaliuk, A. (2015). Tradytsii v rozvytku khoreohrafichnoho mystetstva yak viddzerkalennia sotsiokulturnoi identychnosti [Traditions in the development of choreographic art as a reflection of cultural and socio identity ]. Announcer of H. S. Skovoroda Kharkiv National Pedagogical University. Philosophy. Vol. 45(1). Kharkiv, pp.16-27.[in Ukrainian].

5. Shkorinenko, V. (2003). Narodnyi tanets u tradytsiinii i suchasnii kulturi Ukrainy [Folk dance is in the traditional and modern culture of Ukraine]. Extended abstract of candidate's thesis. Kyiv, 12 p. [in Ukrainian].

6. Fryz, P. (2007). Khoreohrafichna kultura yak chynnyk tvorchoho rozvytku osobystosti dytyny [Choreographic culture as factor of creative development of of child's personality]. Degree of candidate of study of art. Kyiv, 181 p. [in Ukrainian].

Стаття надійшла до редакції 31.07.2018

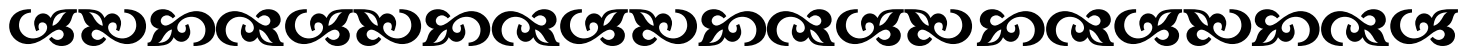

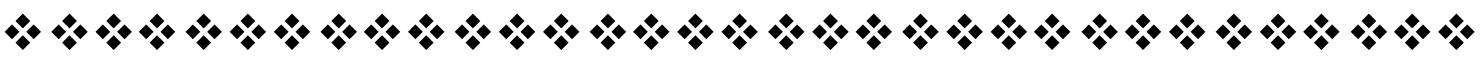

"Я відааю перевагу тому, що можна побачити, почути івивчити".

Теракגim Ефеський давнъогрецький боілособб

“Культура - ие винайдений компроміс: 1. міжлюдиною і Всесвітом; 2. міжлюдиною та іншою людиною; 3. між людиною самою в собі".

Карл Тустав Ннг швейиарський психоаналітик

\section{$\% \%+\%$

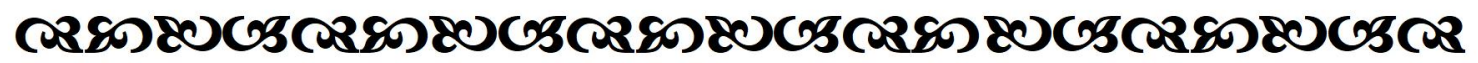

